\title{
Effects of Environmental Temperature, Humidity and Air Movement on Heat Loss Particularly that of Latent Heat, from the Pig
}

Toshihiko KAMADA and Iwao NotsukI

\author{
Department of Agriculture, Faculty of Agriculture, \\ Tokyo University of Agriculture and Technology, Fuchu-shi 183
}

(Received October 31, 1985)

\begin{abstract}
Heat loss from 6 male castrated pigs in response to air temperature $\left(12-33^{\circ} \mathrm{C}\right.$ ), air humidity $(40$ and $70 \%$ ) and air movement (still air and $1.3 \mathrm{~m} / \mathrm{s}$ air flow) was studied. Heat production, water evaporation from the respiratory tract (RWE) and skin surface (SWE), heart rate, respiration rate and rectal temperature were measured for each of these 3 factors of the environment. Heat loss was not significantly effected by environmental condition. RWE and SWE increased with temperature, the increase in RWE being greater. RWE and SWE was significantly lower by the effects of air movement at high temperature. Total water evaporation ( TWE $: \mathrm{g} / \mathrm{kg}^{0.75} \cdot \mathrm{hr}$ ) was estimated from the following equations $\left(X={ }^{\circ} \mathrm{C}\right)$.

In still air

$$
Y=-4.0865+0.9729 X-0.0482 X^{2}+0.009 X^{s}\left(R^{2}=0.837\right)
$$

At an air flow rate of $1.3 \mathrm{~m} / \mathrm{s}$$$
Y=-15.0278+2.2850 X-0.1000 X^{2}+0.016 X^{8}\left(R^{2}=0.734\right)
$$

The ratio of RWE to TWE was about $50 \%$ at $12^{\circ} \mathrm{C}$ and $65-75 \%$ at $33^{\circ} \mathrm{C}$. The ratio of latent heat loss to total heat loss increased from $15 \%$ at $12^{\circ} \mathrm{C}$ to $30-50 \%$ at $33^{\circ} \mathrm{C}$, and the ratio was high when there was air movement. The results obtained for heat production and water evaporation were consistent with those for heart rate, respiration rate and rectal temperature. The modes of heat loss from the pig were concluded to vary with air temperature and movement; the effects of air movement were clear at high temperature. Air movement was found to accelerate sensible heat loss and the need for heat loss as latent heat became less at high temperature. Latent heat loss was little influenced by air humidity.
\end{abstract}

Jpn. J. Zootech. Sci., 58 (2) : 147-154, 1987

Key words : temperature, humidity, air movement, heat loss, pig

Heat loss from the animals to environment was effected by environmental condition. Heat is lost in the forms of sensible heat and latent heat (evaporative heat) and their ratio is also effected by environmental condition.

There are some reports indicating the manner in which temperature effects the amount of heat loss from pigs ${ }^{1-6)}$ and the ratio of sensible heat loss to that of latent heat ${ }^{1,3-6)}$. At low temperature heat loss has been noted to be considerable and also noted that there is the trend such that the lower the temperature, the greater is the 


\section{KAMADA and Notsuki}

sensible heat loss and the higher the temperature, the greater the latent heat loss.

Air humidity and movement are known to modify the effects of air temperature. A few studies have been made to determine effects of air humidity ${ }^{7,8)}$ and air movement ${ }^{1,5)}$ on heat loss from pigs. The effects of air humidity have been investigated at high temperature, as well as those of air movement at rates ranging from 0 to $56 \mathrm{~cm} / \mathrm{s}$. There is thus the need to study air humidity and movement over a wider temperature range and higher rates, respectively, and how they mutually affect each other.

Latent heat loss can be classified as that lost from the skin surface and from the respiratory tract. The effects of air humidity and movement on these modes of evaporation remain to be clarified.

The present experiment was carried out to determine the effects of these two environmental factors on the regulation of body temperature and to summarize the effects of 3 climatic tactors. The data presented in this report may be utilized for the design of more suitable animal housing accomodations.

\section{Materials and Methods}

Six male castrated Landrace pigs were used. Three pigs, $30.6^{-} 34.5 \mathrm{~kg}$ in initial body weight, were used for the experiment conducted in a high temperature range from 22 to $32^{\circ} \mathrm{C}$ and the other $3,36.4-46.1 \mathrm{~kg}$, for the experiment in the low temperature range from 7 to $22^{\circ} \mathrm{C}$. Feed and water were available ad libitum except at the time measurements were made.

The animals were kept in the temperature and humidity controlled room and exposed to 6 different air temperatures : 7, 12, 17, 22, 27 and $32^{\circ} \mathrm{C}$. Two levels each of air humidity (40 and 70\%) and air movement (still air and an air flow rate of $1.3 \mathrm{~m} / \mathrm{s}$ ) were controlled at each temperature. Wind was blown from a fan placed above the pigs.

After all the animals had exposed for more than 40 hours to each of the above temperatures, humidities and air movement, they were fitted with masks, placed in the indirect calorimetric chamber $(1.4 \mathrm{~m} \times 1.1 \mathrm{~m} \times 0.8 \mathrm{~m})$ and exposed again to the same conditions.

Heat production, water evaporation from the respiratory tract (RWE) and skin surface (SWE), heart rate, respiration rate and rectal temperature of each pig were measured continuously over a period of 1 hour and was calculated from the mean of all 5-minute values (minimum 5 readings) when animals were at rest. Heat production was measured with an $\mathrm{O}_{2}$ and $\mathrm{CO}_{2}$ meter. Water evaporation was determined on the basis of differences in dew points between inlet and outlet air of the mask and chamber and calculated by an equation derived by KatAYAMA ${ }^{9)}$. Heart rate, respiration rate and rectal temperature were measured by the telemetry system.

The chamber temperature was made greater than any of the air temperature, and the effects were examined at $12,16,21,25,29$ and $33^{\circ} \mathrm{C}$.

Heat loss by water evaporation was caluculated by multiplying the amount of 


\section{Heat Loss from the Pig}

water evaporation ( $\mathrm{g}$ ) by $2.416 \mathrm{~J}$ (vaporizing energy).

The results were analyzed by the 3-way variance analysis.

\section{Results and Discussion}

Low air humidity (40\%) was not controlled at $7^{\circ} \mathrm{C}$, and its effects at this temperature were not examined.

Changes in heat production in response to the temperature, humidity and air movement are summarized in Table 1. Heat production was seemed to increase below $21^{\circ} \mathrm{C}$ and above $29^{\circ} \mathrm{C}$. Rise in body temperature could not be detected during the each measurement and thus heat production was assumed equal to total heat loss. CLOSE et al. ${ }^{4}$ reported that heat loss from pigs at ad lib feeding level is $42.0 \mathrm{~kJ} / \mathrm{kg}^{0.75} \cdot \mathrm{hr}$ at $10^{\circ} \mathrm{C}, 36.0$ at $20^{\circ} \mathrm{C}$ and 31.9 at $30^{\circ} \mathrm{C}$. These values show close agreement with the data of present research. The significance of temperature, humidity and movement of air is summarized in Table 2. The analysis of variance indicated heat production not to be significantly effected by any of these three factors.

CLose et al. ${ }^{5)}$ observed an increase in air movement from 3 to $56 \mathrm{~cm} / \mathrm{s}$ to increase the heat loss but we could detect no significant effects of this air movement in the

Table 1. Effects of temperature, humidity and air movement on heat production in the pig $\left(\mathrm{kJ} / \mathrm{kg}^{0.75}\right.$. hr $) \quad($ Mean \pm S. D., $\mathrm{N}=3$ )

\begin{tabular}{|c|c|c|c|c|c|c|c|}
\hline & & \multicolumn{6}{|c|}{ Environmental temperature } \\
\hline & & $12^{\circ} \mathrm{C}$ & $16^{\circ} \mathrm{C}$ & $21^{\circ} \mathrm{C}$ & $25^{\circ} \mathrm{C}$ & $29^{\circ} \mathrm{C}$ & $33^{\circ} \mathrm{C}$ \\
\hline \multicolumn{8}{|c|}{ R.H. Air movement } \\
\hline \multirow[t]{2}{*}{$40 \%$} & still air & & $37.6 \pm 6.8$ & $35.3 \pm 4.0$ & $36.5 \pm 4.8$ & $35.5 \pm 6.4$ & $38.3 \pm 5.2$ \\
\hline & $1.3 \mathrm{~m} / \mathrm{s}$ & & $38.5 \pm 2.8$ & $37.4 \pm 1.0$ & $36.8 \pm 2.9$ & $34.6 \pm 2.2$ & $40.3 \pm 5.3$ \\
\hline \multirow[t]{2}{*}{709} & still air & $41.8 \pm 3.5$ & $37.4 \pm 5.6$ & $35.6 \pm 4.0$ & $37.4 \pm 3.6$ & $36.3 \pm 2.5$ & $41.3 \pm 9.8$ \\
\hline & $1.3 \mathrm{~m} / \mathrm{s}$ & $41.3 \pm 2.5$ & $42.5 \pm 0.7$ & $36.1 \pm 6.5$ & $38.9 \pm 3.4$ & $35.5 \pm 1.3$ & $29.9 \pm 0.9$ \\
\hline
\end{tabular}

Table 2. Significance of the effects of temperature, humidity and air movement on parameters caluculated by analysis of variance

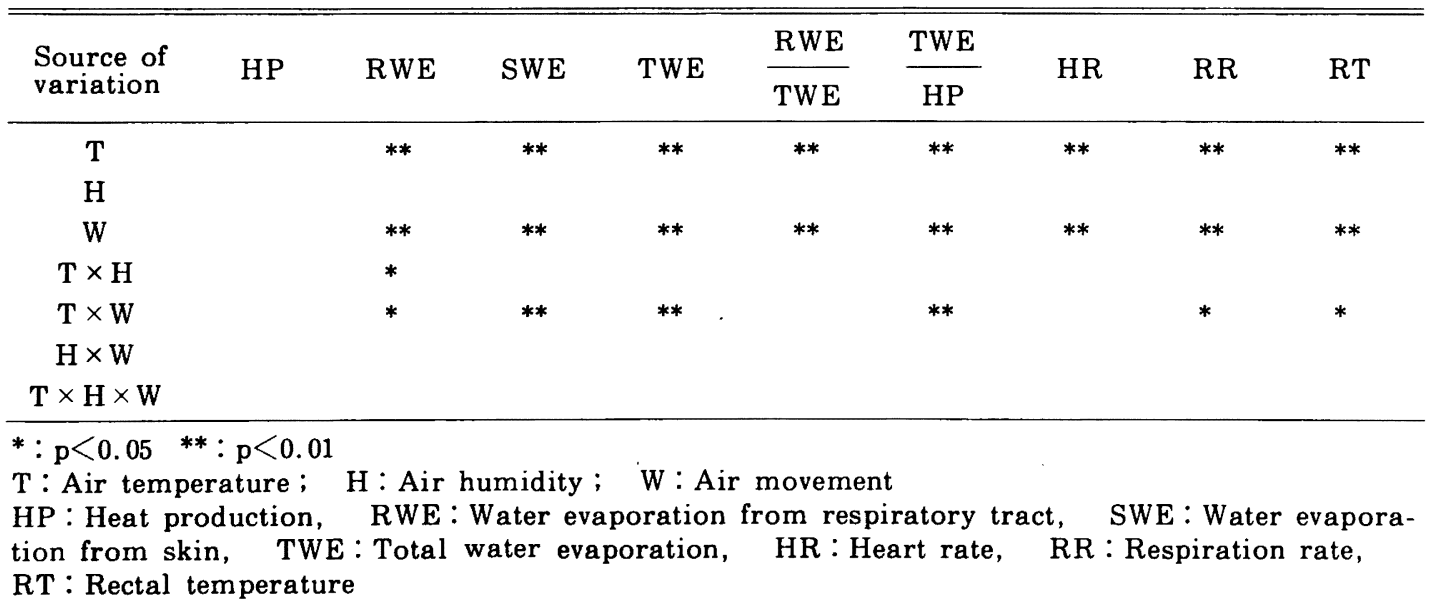


present study.

Changes in heat loss by RWE and its volume are shown in Table 3. RWE did not increase at ambient temperatures below $21^{\circ} \mathrm{C}$ but did so when the air temperature was above this. The effects of the interaction between temperature and humidity on RWE were significant (Table 2) and the analysis showed those of humidity itself at $33^{\circ} \mathrm{C}$ to be significant. Thus at high temperature and humidity, RWE is low, as also noted by Morrison et al. ${ }^{8}$. The highest temperature used by Morrison was $30^{\circ} \mathrm{C}$ at which he observed air humidity to have effect on heat loss but in the present research, we could detect none. This may be due to the fact that the relative humidity in Morrison's study was $90 \%$ as opposed to $70 \%$ in our experiment, thus making the effect of humidity more pronounced.

Air movement significantly decreased RWE at temperatures above $25^{\circ} \mathrm{C}$ and may possibly lessen the effect of heat on this parameter.

SWE was noted to change less than RWE (Table 3). At high temperature, SWE increased but slightly with air temperature, particularly when there was no air movement, indicating SWE to possibly not be essential to bring about heat loss at high temperature. SWE was significantly affected in the same manner as RWE (Table 2).

The values in this study for RWE and SWE were essentially in agreement with those of Morrison et al. ${ }^{8)}$ at the same temperature.

Total water evaporation ( $T W E=R W E+S W E$ ) showed a marked increase above $25^{\circ} \mathrm{C}$. Air movement was significant at 29 and $33^{\circ} \mathrm{C}$ but not humidity at any temperature at which observation was made (Table 2). Two regression equations with high contribution were derived on the basis of the data obtained.

In still air,

$$
Y=-4.0865+0.9729 X-0.0482 X^{2}+0.009 X^{3}\left(\mathrm{R}^{2}=0.837\right)
$$

And at an air flow rate of $1.3 \mathrm{~m} / \mathrm{s}$,

Table 3. Effects of temperature, humidity and air movement on heat loss by water evaporation from the respiratory tract $(\mathrm{RWE})$ and the skin (SWE) $\left(\mathrm{kJ} / \mathrm{kg}^{0.75}\right.$. hr) $(\mathrm{Mean} \pm \mathrm{S} . \mathrm{D} ., \mathrm{N}=3)$

\begin{tabular}{|c|c|c|c|c|c|c|c|}
\hline \multirow{2}{*}{\multicolumn{2}{|c|}{ RWE }} & \multicolumn{6}{|c|}{ Environmental temperature } \\
\hline & & \multirow[t]{2}{*}{$12^{\circ} \mathrm{C}$} & \multirow[t]{2}{*}{$16^{\circ} \mathrm{C}$} & \multirow[t]{2}{*}{$21^{\circ} \mathrm{C}$} & \multirow[t]{2}{*}{$25^{\circ} \mathrm{C}$} & \multirow[t]{2}{*}{$29^{\circ} \mathrm{C}$} & \multirow[t]{2}{*}{$33^{\circ} \mathrm{C}$} \\
\hline R.H. & Air movement & & & & & & \\
\hline $40 \%$ & still air & & $2.9 \pm 1.0$ & $4.1 \pm 1.1$ & $6.0 \pm 2.6$ & $6.8 \pm 1.9$ & $12.6 \pm 2.4$ \\
\hline & $1.3 \mathrm{~m} / \mathrm{s}$ & & $2.3 \pm 0.3$ & $3.2 \pm 0.6$ & $4.1 \pm 1.1$ & $3.7 \pm 0.7$ & $9.6 \pm 2.1$ \\
\hline \multirow[t]{2}{*}{$70 \%$} & still air & $3.2 \pm 1.0$ & $2.9 \pm 0.8$ & $3.9 \pm 1.1$ & $5.4 \pm 2.2$ & $7.7 \pm 0.5$ & $10.3 \pm 0.3$ \\
\hline & $1.3 \mathrm{~m} / \mathrm{s}$ & $3.0 \pm 0.6$ & $2.8 \pm 0.4$ & $3.8 \pm 2.0$ & $3.6 \pm 0.7$ & $4.9 \pm 0.2$ & $6.6 \pm 0.5$ \\
\hline \multicolumn{8}{|c|}{ SWE } \\
\hline R.H. & Air movement & & & & & & \\
\hline \multirow[t]{2}{*}{$40 \%$} & still air & & $2.5 \pm 0.4$ & $2.4 \pm 0.7$ & $2.9 \pm 0.1$ & $6.8 \pm 1.4$ & $6.1 \pm 1.3$ \\
\hline & $1.3 \mathrm{~m} / \mathrm{s}$ & & $2.4 \pm 0.5$ & $1.8 \pm 0.4$ & $2.7 \pm 0.3$ & $3.2 \pm 0.4$ & $3.4 \pm 0.3$ \\
\hline \multirow[t]{2}{*}{$70 \%$} & still air & $2.4 \pm 0.3$ & $2.1 \pm 0.2$ & $2.3 \pm 0.4$ & $2.5 \pm 0.3$ & $4.6 \pm 0.3$ & $6.0 \pm 0.6$ \\
\hline & $1.3 \mathrm{~m} / \mathrm{s}$ & $2.8 \pm 0.3$ & $2.3 \pm 0.5$ & $2.9 \pm 0.2$ & $2.8 \pm 0.5$ & $2.4 \pm 0.2$ & $2.9 \pm 0.1$ \\
\hline
\end{tabular}




\section{Heat Loss from the Pig}

$$
Y=-15.0278+2.2850 X-0.1000 X^{2}+0.016 X^{3}\left(\mathrm{R}^{2}=0.734\right)
$$

where $Y_{1}$ and $Y_{2}$ are TWE $\left(\mathrm{g} / \mathrm{kg}^{0.75} \cdot \mathrm{hr}\right)$ and $X$ is the air temperature $\left({ }^{\circ} \mathrm{C}\right)$. These equations should be useful for the design of pig housing. TWE was caluculated to be $3.29 \mathrm{~g} / \mathrm{kg}^{0.75} \cdot \mathrm{hr}$ at $20^{\circ} \mathrm{C}$ and $6.02 \mathrm{~g}$ at $30^{\circ} \mathrm{C}$ for an air flow rate of $1.3 \mathrm{~m} / \mathrm{s}$.

Air movement had no effect on total heat loss but caused an increase in the loss of sensible heat thus the requirement for heat loss by water evaporation less. This would explain the lowering of TWE.

Changes in the ratio of RWE to TWE are shown in Fig. 1. RWE was 50-60\% of TWE below $20^{\circ} \mathrm{C}$ but increased to $70 \%$ at high temperature. The effects of humidity and air movement were not significant (Table 2). The maximum value of the ratio of RWE to TWE in this experiment was $74 \%$ at $33^{\circ} \mathrm{C}$, exceeding the $66 \%$ obtained by MorRison et al. at $30^{\circ} \mathrm{C}$ and $90 \%$ R.H. ${ }^{8)}$. This indicates RWE to have relative importance at high temperature.

Changes in the ratio of latent heat loss (water evaporation) to total heat loss are shown in Fig. 2. This ratio increased from about $15 \%$ at $12^{\circ} \mathrm{C}$ to $30-50 \%$ at $33^{\circ} \mathrm{C}$ and were in agreement with those of the data by Close et al. ${ }^{5)}$ about $20 \%$ at $10^{\circ} \mathrm{C}$ and $50 \%$ at $30^{\circ} \mathrm{C}$. Above $25^{\circ} \mathrm{C}$, the ratio was significantly decreased by air movement (Table 2). That is, air movement brought about an increase in the ratio of sensible heat loss to latent heat loss. The present study shows that a good estimate of the sensible heat loss is got by the curviliner regressions of the total heat loss and the ratio of latent heat loss to total heat loss and third degree polynomial is found to fit the data satisfactory. Some of the values for this parameter are shown in Table 4 . The effect

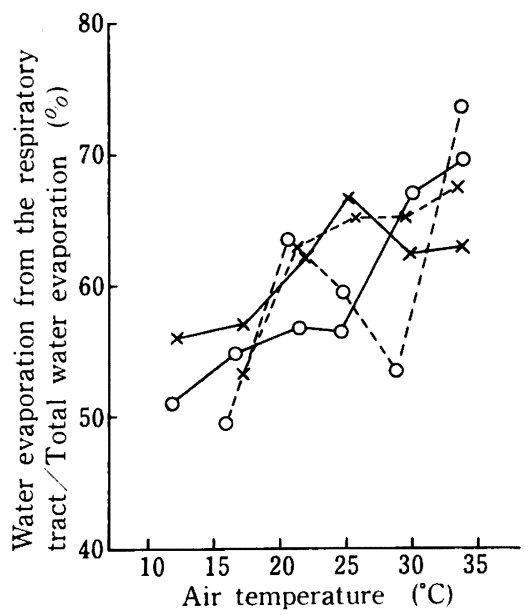

Fig. 1. Effects of temperature, humidity and air movement on the ratio of water evaporation from the respiratory tract to total water evaporation from the pig.

$\times \cdots \cdots \times: 4096$ air humidity, still air

$\bigcirc \cdots \bigcirc: 4096$ air humidity, $1.3 \mathrm{~m} / \mathrm{s}$ air flow

$x-x: 70 \%$ air humidity, still air

$\mathrm{O}-\mathrm{O}: 70 \%$ air humidity, $1.3 \mathrm{~m} / \mathrm{s}$ air flow 


\section{KAMADA and NoTSUKI}

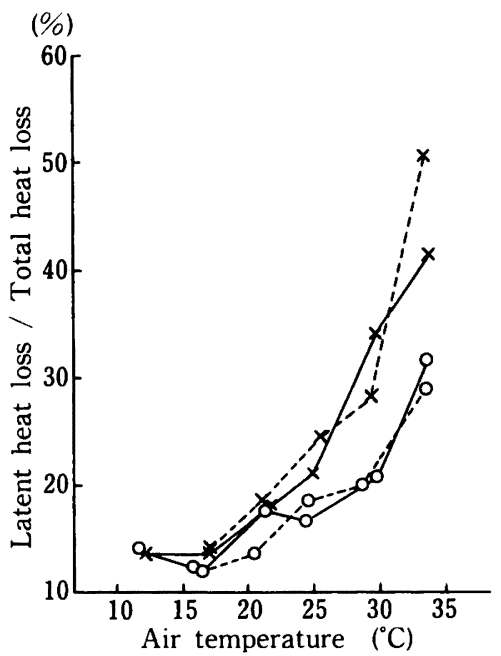

Fig. 2. Effects of temperature, humidity and air movement on the ratio of latent heat loss to total heat loss from the pig.

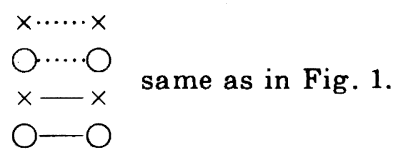

Table 4. Estimated sensible heat loss at each temperature $\left(\mathrm{kJ} / \mathrm{kg}^{0.75} . \mathrm{hr}\right)$

\begin{tabular}{|c|c|c|c|c|c|c|}
\hline & \multicolumn{5}{|c|}{ Environmental temperature $\left({ }^{\circ} \mathrm{C}\right)$} & \\
\hline & 13 & 18 & 23 & 28 & 33 & \\
\hline \multicolumn{7}{|c|}{ Air movement } \\
\hline Still air & 35.25 & 31.34 & 28.75 & 26.17 & 26.17 & \\
\hline $1.3 \mathrm{~m} / \mathrm{s}$ & 35.50 & 33.79 & 31.46 & 28.63 & 25.13 & \\
\hline \multicolumn{7}{|c|}{ Equation for estimating total heat loss } \\
\hline & \multicolumn{5}{|c|}{$Y=$ Total heat loss $\left(\mathrm{kJ} / \mathrm{kg}^{0.75} \cdot \mathrm{hr}\right) \quad X={ }^{\circ} \mathrm{C}$} & \\
\hline in still air & \multicolumn{5}{|c|}{$Y=-0.00013 X^{3}+0.0538 X^{2}-2.3219 X+62.1237$} & $\left(R^{2}=0.890\right)$ \\
\hline \multicolumn{7}{|c|}{ at air flow rate of $1.3 \mathrm{~m} / \mathrm{s}$} \\
\hline & \multicolumn{5}{|c|}{$Y=0.00042 X^{3}-0.0333 X^{2}+0.2417 X+42.2030$} & $\left(R^{2}=0.900\right)$ \\
\hline \multicolumn{7}{|c|}{ Equation for estimating the ratio of latent heat loss to total } \\
\hline heat loss & \multicolumn{5}{|c|}{$Y=$ the raio $\quad X={ }^{\circ} \mathrm{C}$} & \\
\hline in still air & \multirow{2}{*}{\multicolumn{5}{|c|}{$\begin{array}{l}Y=0.0035 X^{3}-0.1443 X^{2}+2.2801 X+0.4292 \\
3 \mathrm{~m} / \mathrm{s}\end{array}$}} & $\left(R^{2}=0.997\right)$ \\
\hline at air flow rate of $1.3 \mathrm{~m} / \mathrm{s}$ & & & & & & \\
\hline & \multicolumn{5}{|c|}{$Y=0.0016 X^{3}-0.0593 X^{2}+0.7037 X+10.7148$} & $\left(\mathrm{R}^{2}=0.968\right)$ \\
\hline
\end{tabular}

of air movement has been reported to be the same as that of a decrease in temperature ${ }^{5}$. The pig has a limited ability to eliminate water through evaporation and thus sensible heat loss may possibly be increased through air movement control.

Heart rate showed a positive correlation to heat production at low temperature.

The respiration rate was found to increase in direct proportion to RWE (Fig. 3). Respiration rate was increased with temperature rise and in still air more respiration 
Heat Loss from the Pig

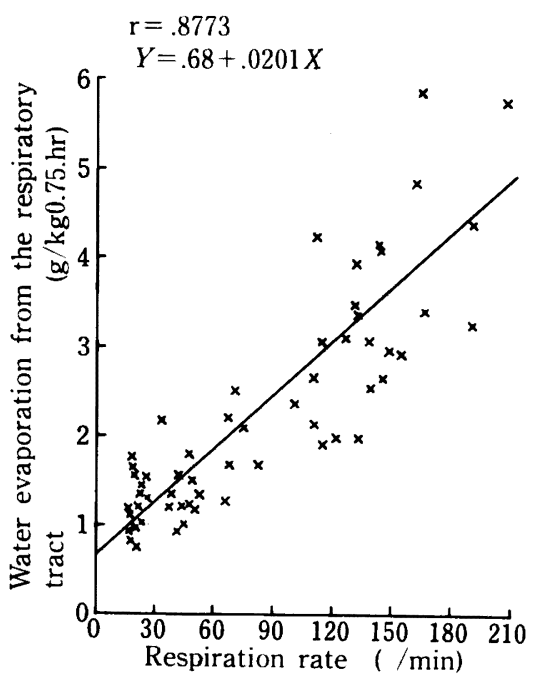

Fig. 3. The relationship between respiration rate and water evaporation from respiratory tract of the pig.

rate was observed. Thus, when sensible heat loss and that from the skin are restricted in still air, a greater amount of heat must be liberated from the respiratory tract. Respiration was confirmed to be essential for heat loss, particularly so at high temperature.

Rectal temperature was higher above $25^{\circ} \mathrm{C}$. But at same temperature it was lower in still air, thus indicating air movement to accelerate heat loss.

Based on the data obtained in the present research, heat loss is concluded to be significantly affected by air movement at high temperature and air movement is effective to alleviate heat stress in the pig. Air humidity has little effect on heat loss.

This work was supported by a Grant-in-Aid (No. 56480059) from the Ministry of Education, Japan.

\section{References}

1) Holmes, C.W. and L.E. Mount, Anim. Prod., 9:435-452. 1967.

2) Verstegen, M.W.A., W.H. Close, I.B. Start and L.E. Mount, Br. J. Nutr., $30: 21-$ 35. 1973.

3) Close, W.H. and L.E. Mount, Br. J. Nutr., 34:279-290. 1975.

4) Close, W.H. and L.E. Mount, Br. J. Nutr., 40:413-421. 1978.

5) Close, W.H., R.P. Heavens and D. Brown, Anim. Prod., 32:75-84. 1981.

6) Close, W.H. and M.W. Stainer, Anim. Prod., 38:221-231. 1984.

7) Ingram, D.L., Res. Vet. Sci., 6:9-17. 1965.

8) Morrison, S.R., T.E. Bond and H. Heitman, Jr., Trans. ASAE., $10: 691-696.1967$.

9) Katayama, S., J. Soc. Agr. Struc. Jpn., $9: 39-45.1979$. 
豚の体熱放散, 特に潜熱による体熱放散に及ぼす気温,

気湿および気動の影響

鎌田寿彦・野附 厳

東京農工大学農学部, 府中市 183

豚舎の設計に必要な基礎資料を得るために，各種気象 環境下における豚の体熱放散経路と放熱量を調べた．実 験には肥育豚を用い環境制御室内で気温 $\left(12 \sim 33^{\circ} \mathrm{C}\right)$, 気湿 $(40 \%$ 之 $70 \%)$ および気動（無風之 $1.3 \mathrm{~m} / \mathrm{s}$ の風 速）を変化させて, 豚の体熱生産量, 呼吸器ならびに体 表面からの潜熱による体熱放散量を測定した。体熱生産 量は呼気ガスの分析により求めた。体熱放散量のうち潜 熱放散量は供試豚を収容したチャンバーおよび装着した マスクの給気と排気の露点差から求めた。顕熱放散量は 体熱生産量一潜熱放散量とした。

全熱放散量には気温, 気湿および気動による有意な影 響はみられなかった，潜熱放散量は気温の上昇に伴って 增加したが, 特に呼吸器からの増加が著しかった。気動
は高温時において呼吸器ならびに体表面からの潜熱放散 量を有意に減少させた．気湿は高温環境下の低湿時にの み呼吸器からの潜熱放散量を減少させたが，それ以外は 影響がみられなかった。潜熱放散量中呼吸器からの放散 量が占める割合は気温の上昇に伴って増加した．全熱放 散量に占める潜熱放散割合も気温の上昇に伴って明らか に増加したが, 同一気温では気動がある場合，乙の割合 は小さくなった．潜熱放散量を水分蒸散量で示すと代謝 体重・ 1 時間当り $13^{\circ} \mathrm{C}$ 無送風の場合 $2.39 \mathrm{~g}, 1.3 \mathrm{~m}$ 送 風の場合 $1.07 \mathrm{~g}, 33^{\circ} \mathrm{C}$ 無送風の場合 $7.09 \mathrm{~g}, 1.3 \mathrm{~m}$ 送 風の場合 $5.38 \mathrm{~g}$ であった。

日畜会報， 58 (2)：147-154，1987 